\title{
Regulatory Volume Increase and Regulatory Volume Decrease Responses in HL-1 Atrial Myocytes
}

\author{
Veronica I. Cacace ${ }^{a}$ Andres G. Finkelsteyn ${ }^{c}$ Laura M. Tasso ${ }^{b}$ Carlos F. Kusnier ${ }^{a}$ \\ Karina A. Gomez ${ }^{\mathrm{b}}$ Jorge Fischbarg ${ }^{\mathrm{a}}$ \\ anstituto de Investigaciones Cardiologicas "Profesor Alberto Taquini" (ININCA), Facultad de Medicina, \\ Universidad de Buenos Aires; y CONICET, 'Instituto de Investigaciones en Ingeniería Genética y Biología \\ Molecular (INGEBI and CONICET), Consejo Nacional de Investigaciones Científicas y Tecnológicas \\ (CONICET), 'Instituto del Cálculo, Facultad de Ciencias Exactas y Naturales, Universidad de Buenos \\ Aires, Buenos Aires, Argentina
}

\section{Key Words}

$\mathrm{HL}-1$ atrial myocytes $\bullet$ Cell volume regulation $\bullet \mathrm{RVI} \bullet \mathrm{RVD} \bullet$ Bumetanide $\bullet$ DIDS

\begin{abstract}
Background/Aims: we have investigated whether cultured cardiomyocytes of the cell line HL-1 have the ability to perform regulatory volume responses both in hypotonic and hypertonic conditions. Furthermore, we characterized those regulatory responses and studied the effects of bumetanide and DIDS in volume regulation of HL-1 cells. Methods: we used a light scattering system to measure the transient volume changes of $\mathrm{HL}-1$ cells when subjected to osmotic challenge. Results: We found that HL-1 cells correct for their volume excess by undergoing regulatory volume decrease (RVD), and also respond to hypertonic stress with a regulatory volume increase (RVI). Rate of RVD was $0.08 \pm 0.04$ intensity/min, and rate of RVI was $0.09 \pm 0.01$ intensity/min. Volume recovery was $83.68 \pm 5.73 \%$ for RVD and $92.3 \pm 2.3 \%$ for RVI. Bumetanide $50 \mu \mathrm{M}$ inhibited volume recovery, from $92.3 \pm 2.3 \%$ (control) to $24.6 \pm$ $8.8 \%$ and reduced the rate of RVI from $0.070 \pm 0.020$ intensity $/ \mathrm{min}$ (control) to $0.010 \pm 0.005$ intensity/min. $50 \mu \mathrm{M}$ DIDS reduced volume recovery to $42.93 \pm 7.7 \%$ and rate of RVI, to 0.03 \pm 0.01 intensity/min. Conclusions: these results suggest that bumetanide- and DIDS-sensitive mechanisms are involved in the RVI of $\mathrm{HL}-1$ cells, which points to the involvement of the $\mathrm{Na}^{+}$/ $\mathrm{K}^{+} / 2 \mathrm{Cl}^{-}$cotransporter and $\mathrm{Cl}^{-} /$bicarbonate exchanger in $\mathrm{RVI}$, respectively.
\end{abstract}

Copyright (C) 2014 S. Karger AG, Basel 


\section{Introduction}

The ability to control cell volume is essential for cellular function [1-3]. Mechanisms involved include cell membrane proteins such as ion channels, transporters, ionic pumps and cytoskeletal proteins. Disturbances in cell volume activate several signaling pathways, resulting in adaptive and protective effects in cells [3]. Following an osmotic shock, changes in the volume of cells show two dynamic phases. In the first one, which lasts a few seconds to minutes, water rushes osmotically across the plasma membrane. In the second phase, the cell undergoes a process of volume regulation; induced cell swelling is followed by regulatory volume decrease (RVD), and induced cell shrinking is followed by regulatory volume increase (RVI) [1,3].

During RVD, osmotically swollen cells release $\mathrm{K}^{+}, \mathrm{Cl}^{-}$, organic osmolytes, and water [1, 3]. A variety of cell membrane transport mechanisms are involved in RVD such as swellingactivated $\mathrm{Cl}^{-}$channels, organic osmolyte channels, and swelling-activated $\mathrm{K}^{+}$channels $[1,3$, 4]. On the other hand, the RVI response occurs by gain of water, $\mathrm{Na}^{+}$and $\mathrm{Cl}^{-}[1,3,4]$. In the majority of cells, RVI is mediated by the $\mathrm{Na}^{+} / \mathrm{K}^{+} / 2 \mathrm{Cl}^{-}$cotransporter (NKCC), and the $\mathrm{Na}^{+} / \mathrm{Cl}^{-}$ symporter [4-6]. In other cases, an important role is played by the parallel activation of the $\mathrm{Na}^{+} / \mathrm{H}^{+}$exchanger (NHE) and $\mathrm{Cl}^{-} / \mathrm{HCO}^{-}$anion exchanger $[1,3,7,8]$.

Cardiac cells have been found to regulate their volume by RVD when subject to swelling by hypotonic stress [9]. The RVD response in cardiac myocytes has been studied from the following models: embryonic chicken, neonatal rat, guinea pig, rabbit adult ventricular myocytes and mouse adult atrial myocytes [10-16]. Cultured chick embryo cardiac myocytes $[17,18]$, ventricular rat myocytes [15], adult rabbit ventricular myocytes [19] and mouse atrial myocytes [16] can exhibit RVD. However, others reported the absence of spontaneous RVD in neonatal rat and guinea pig cardiac myocytes [10, 13, 20, 21]. Evidently there are differences, either between the different cardiac cell models, or in the experimental conditions.

Furthermore, in cardiac myocytes, $\mathrm{K}^{+}$chanels, $\mathrm{Cl}^{-}$Channels, and volume regulated anion channels have been described as involved in cell volume regulation [15, 22], and the coordinate action of $\mathrm{Cl}^{-}$and $\mathrm{K}^{+}$channels could be the principal mechanism for RVD [23].

All the transport mechanisms mentioned above in connection with RVI in other cells are also present in cardiac myocytes. However, to date, there are no reports of RVI in cardiac cells $[9,10,23-25]$.

In some pathological conditions such as ischemia/reperfusion, hypovolemia, hypernatremia, diabetic shock, or septic shock cardiac cells are exposed to hyposmotic as well as hyperosmotic stress. Alterations in cell volume may seriously affect cardiac function [26]. Cell swelling represents a major threat to the heart by promoting the development of arrhythmias [27]; chronically, it can increase infarct size [28]. In the other hand, hyperosmotic stress reduces cardiac contractibility [29] and can induce apoptotic responses in cardiomyocytes leading to cell death [24]. So, the ability to regulate cell volume is important for the maintenance of cardiac function and homeostasis.

Since we had developed a suitable method to study cell volume changes [30, 31], we thought it would be useful to reinvestigate the situation in cardiac myocytes. We found that HL-1 cardiac myocytes can regulate their volume, both when subject to swelling by hypotonic challenge by regulatory volume decrease (RVD) and when subject to hypertonic stress with a classical regulatory volume increase (RVI). In addition, we found that RVI can be partially inhibited by both bumetanide and DIDS which points to the involvement of the $\mathrm{Na}^{+} / \mathrm{K}^{+} / 2 \mathrm{Cl}^{-}$cotransporter and $\mathrm{Cl}^{-} /$bicarbonate exchanger in the RVI response, respectively.

\section{Materials and Methods}

\section{Cell preparation}

A murine HL-1 atrial cardiac myocyte cell line was used. Cells were acquired in passage 37 and cultured as described in the literature [32]. Cells were cultured in Claycomb medium supplemented with 
Fig. 1. Schematic diagram illustrating the experimental setup for cell volume measurements. The angular orientation $\left(45^{\circ}\right)$ between incident laser light and coverglass is shown.

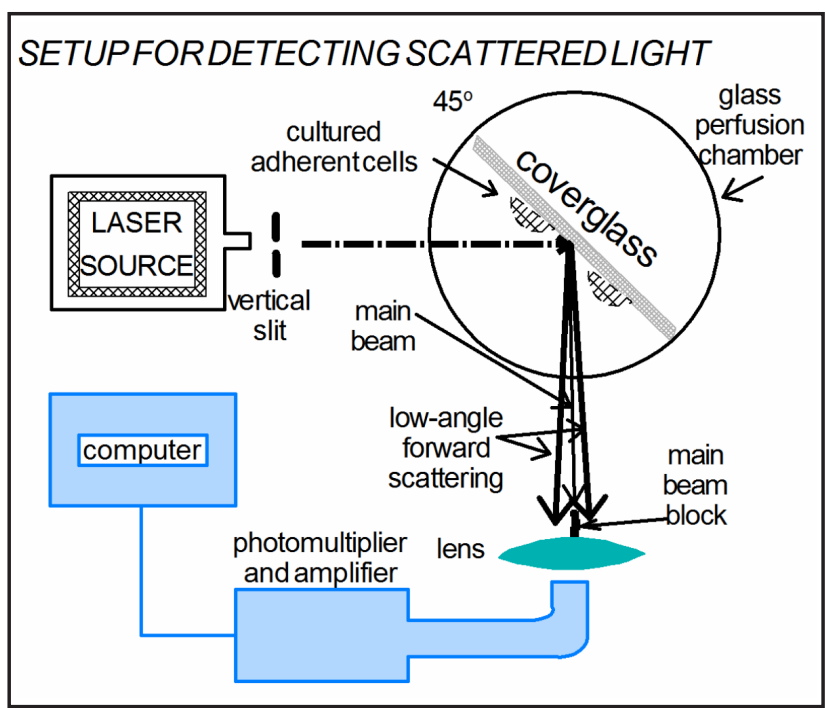

FBS $10 \% \mathrm{v} / \mathrm{v}$, streptomycin $100 \mathrm{U} / \mathrm{ml}$, penicillin $100 \mu \mathrm{g} / \mathrm{ml}$ and L-glutamine $2 \mathrm{mM}$. To harvest cells, we used a solution of trypsine/EDTA $0.05 \% / 0.02 \%$ (p/v) [32]. For experiments, cells between passages 45-57 were layered on rectangular glass coverslips (11 x $22 \mathrm{~mm}$, Thomas Scientific @. Cat. \# 6663-F10) previously covered by a matrix of gelatine $0.02 \%(\mathrm{p} / \mathrm{v})$ - fibronectine $0.5 \%(\mathrm{p} / \mathrm{v})$. Coverslips were incubated on culture medium at $37^{\circ} \mathrm{C}$ for $2-3$ days to obtain $80 \%$ confluence $\left(7.5 .10^{5}\right.$ cells $\left./ \mathrm{cm}^{2}\right)$.

\section{Experimental chamber}

Briefly, coverslips with cells were inserted in a plastic plug that has an adjustable slot for this purpose. The plug was placed as the cover for a small cylindrical vessel of glass previously filled with experimental solution. The top of the plastic plug has two openings with tubes of stainless steel (20 gauge) for entry and exit of solutions. Thanks to two rubber 0 rings, the closure is hermetical, so that movements of liquid are forced. This vessel is maintained at $37 \mathrm{C}$.

\section{Solutions}

The control solution was isotonic Ringer's solution containing (in $\mathrm{mM}$ ) $\mathrm{NaCl}$ 107.9, $\mathrm{NaHCO}_{3-}$ 37.0, $\mathrm{KCl}$ 4.7, $\mathrm{NaH}_{2} \mathrm{PO}_{4}$ 1.0, $\mathrm{MgSO}_{4}$ (7. H2O) 0.4, $\mathrm{CaCl}_{2}\left(2 . \mathrm{H}_{2} \mathrm{O}\right)$ 1.8, glucose 5.6, HEPES Na${ }^{+}$10.0, (pH: 7.4). At the beginning of each experiment, cells were equilibrated for $30 \mathrm{~min}$ in control solution. For osmotic challenge, the bathing medium was substituted with $20 \%$ hypotonic (distilled water dilution) or $20 \%$ hypertonic (sucrose added) Ringer's solutions. After each challenge, cells were returned to isotonic solution; recovery took 10-20 min. For inhibition experiments, bumetanide $50 \mu \mathrm{M}$ and 4,4'-Diisothiocyano2,2'-stilbenedisulfonic acid (DIDS) $50 \mu \mathrm{M}$ were used. Bumetanide is a specific inhibitor of $\mathrm{Na}^{+} / \mathrm{k}^{+} / 2 \mathrm{Cl}^{-}$ cotransporter while DIDS is a specific inhibitor of the $\mathrm{Cl}^{-} /$bicarbonate exchanger. Cells in isotonic Ringer were incubated with the inhibitor for $10 \mathrm{~min}$ prior and during osmotic challenge.

\section{Changes of cell volume - light scattering}

To estimate changes in cellular volume, we used the intensity of the light scattered by the cultured cells. The method has been described and validated in the literature [30, 31, 33-37]. For illumination, a small laser-diode was used (model L52-265, Edmund Scientific, $4.2 \mathrm{mw}, \lambda=670 \mathrm{~nm}$ ), generating a beam of rectangular profile reduced to a width of $1.5 \mathrm{~mm}$ by a variable adjustable slit. The coverslip bearing the cells is oriented $45^{\circ}$ to the incident laser light beam (Fig. 1). After the main illuminating beam already scattered emerges from the sample, the intensity of light scattered at small angles carries information on cell volume as previously described $[30,36,37]$. This scattered light is captured through a lens endowed with a black plastic ( $1 \mathrm{~mm}$ wide) central band to block the laser main beam, and is measured with a photomultiplier (Hamamatsu R 928) at a fixed gain (-140 V dynode potential). The photomultiplier output (in $\mu$ Amp) was converted into voltage and amplified through a Chem-Clamp (SN050302, Dagan). This signal was digitized (at $10 \mathrm{KHz}$ ) by an analog-digital conversor Digi-data 1440, and it was recorded with Pclamp $10 \AA$ software. Finally, the output of digitized data was normalized as $\mathrm{Y}(\mathrm{t})=\left(\mathrm{I}-\mathrm{I}_{0}\right) / \mathrm{I}_{0}$, where $\mathrm{Y}(\mathrm{t})$ is the normalized light 
scatter, I is the experimentally measured light intensity, and $\mathrm{I}_{0}$ is the basal light intensity (scatter (at rest) in isotonic solution).

\section{Data analysis}

Since volume changes result from two time-dependent processes (osmotic and regulatory changes), we fit the data to a double-exponential function. This approach has been used previously $[34,37,38]$. The fitting function is:

$Y(t)=A_{1}^{*}\left(1-\exp \left(-t / t_{1}\right)\right)+A_{2}^{*}\left(1-\exp \left(-t / t_{2}\right)\right)(1)$

where $Y(t)$ is given above, $A_{1}$ the (signed) amplitude of the osmotic response, $A_{2}$ the (signed) amplitude of the regulatory volume response, $t_{1}$ the time constant for the osmotic response, and $t_{2}$ the time constant for the volume regulatory response.

The fitting function was used to calculate several parameters of biological interest, namely: the osmotic time, the maximum rate of the osmotic phase, maximum rate of the regulatory phase, the percent of volume recovery, and the maximum value of $\mathrm{Y}(\mathrm{t})$.

The osmotic time is defined as the point at which the fitting function reaches its extreme value. It is calculated by taking the derivative of equation (1) and equating it to zero:

$\mathrm{T}_{\text {osm }}=\ln (-\mathrm{A} 1 * \mathrm{t} 2 /(\mathrm{t} 1 * \mathrm{~A} 2)) /(1 / \mathrm{t} 1-1 / \mathrm{t} 2)(2)$

The maximum rate of the osmotic process is defined as the derivative of the osmotic exponential function evaluated at the initial time, and is calculated as:

$\mathrm{R}_{\text {osm }}=\mathrm{A}_{1} / \mathrm{t}_{1}(3)$

The maximum rate of the regulatory process is defined analogously as the derivative of the regulatory exponential function evaluated at the initial time and is calculated as:

$\mathrm{R}_{\mathrm{reg}}=\mathrm{A}_{2} / \mathrm{t}_{2}(4)$

The percentage of recovery $\left(\mathrm{P}_{\mathrm{R}}\right)$ is defined as the percentage of the maximum regulatory change respect to the peak value of $\mathrm{Y}(\mathrm{t})\left(\mathrm{Y}_{\text {peak }}\right)$. It was calculated as:

$\mathrm{P}_{\mathrm{R}}=100 *\left(\mathrm{Y}_{\text {peak }}-\mathrm{Y}_{\text {as }}\right) / \mathrm{Yp}_{\text {peak }}(5)$

where $\mathrm{Y}_{\mathrm{as}}$ is the asymptotic value of $\mathrm{Y}(\mathrm{t})$.

Statistics

All data are given as means \pm standard error. Comparisons between treatments were done using a oneway analysis of variance (one-way ANOVA) and contrasts were performed with the Bonferroni test. When two groups were compared a t-test was used. All statistic analyses were performed using Originlab software ®. Statistical significance was set at the conventional $5 \%$ level $(\mathrm{p}<0.05)$.

Reagents

Unless noted, all chemicals were purchased from Sigma Aldrich (St Louis, MO, USA). Bumetanide and 4,4'-diisothiocyano-2,2'-stilbene-disulfonic acid (DIDS) were obtained from GIBCO, Life Technologies, USA.

\section{Results}

Osmotic responses, and subsequent volume regulatory responses: RVD and RVI

We studied the changes in volume of cultured cardiac myocytes following osmotic challenges with $20 \%$ hypertonic and $20 \%$ hypotonic Ringer solutions.

HL-1 cells responded with swelling after hypotonic challenge, and with shrinkage after hypertonic challenge. Subsequently, as in other cells, we observed that processes of volume regulation developed in both directions; regulatory volume decrease (RVD), and regulatory volume increase (RVI). Figure 2 show the responses of RVI (Fig. 2, upper panel), and RVD (Fig. 2, lower panel) after exposure to solutions $20 \%$ hypertonic or $20 \%$ hypotonic, respectively. Volume regulatory responses took 6-11 $\mathrm{min}$ for hypertonic challenge, and 8-15 min for hypotonic challenge; after replenishment in control (isotonic) solution, these regulatory responses were maintained even after repeating the osmotic challenge four times. In addition, volume post-regulatory changes occurred after both the RVI and RVD phases when cells were returned to isotonic solution. Thus, in cells treated previously with 
Fig. 2. Cell volume regulation in HL-1 cells. Upper panel. Representative experiment showing a transition from isotonic Ringer to 20 \% hypertonic Ringer, and finally, return to isotonic solution in HL-1 cells. Cells initially shrunk and then underwent an RVI response. With the return to isotonic solution, cell swelling occurs and then cells undergo a postRVI RVD response. The RVI phase of the volume transient lasted some 8-9 min, and the RVD phase, about 7 min. Lower panel. HL-1 cells exposed to $20 \%$ hypotonic medium, initially swell, and then undergo an RVD response. With the return to isotonic solution, the cells shrinked (below their resting volume) and then underwent a post-RVD RVI response. The RVD phase of the volume transient lasted approximately $10 \mathrm{~min}$, and the RVI phase, was incipient and lasted about $3 \mathrm{~min}$.

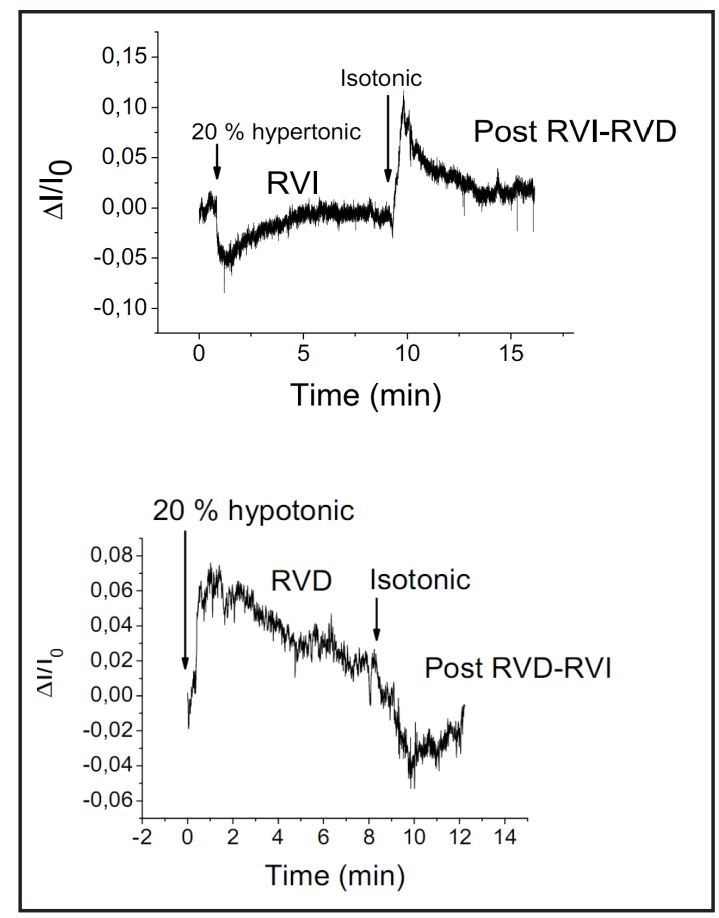

$20 \%$ hypertonic solution (Fig. 2, upper panel), there was a post-RVI-RVD after exposure to isotonic solution; and there was a post-RVD-RVI after return to isotonic solution in the cells previously exposed to $20 \%$ hypotonic solution (Fig. 2, lower panel).

\section{Comparison of the RVD and RVI processes}

To study the dynamic features of osmotic and regulatory responses, we determined the parameters of double exponential fit to the experimental data (Fig. 3). Thus we obtained the osmotic time $\mathrm{T}_{\text {osm }}$, the $\Delta \mathrm{I} / \mathrm{I}_{0}$ peak (normalized light scattered light peak after anisotonic challenge, in absolute values at $\mathrm{T}_{\text {osm }}$ ), the rate of recovery of cell volume during RVD and RVI, and the rates for osmotic change and regulatory responses. We found that the osmotic volume changes were definitely faster than the regulatory changes: the rate of osmotic phases (ie: cell swelling/cell shrinkage) was $0.39 \pm 0.15$ intensity/min for hypotonic challenge $(\mathrm{n}=6)$, and $0.46 \pm 0.06$ intensity/min for hypertonic challenge $(\mathrm{n}=7)$ without significant differences between them (Fig. 4). Instead, the rates for the regulatory phases were $0.08 \pm$ 0.04 intensity/min (RVD), $(\mathrm{n}=6)$ and $0.09 \pm 0.01$ intensity/min (RVI), (n=7), although the differences were not significant again (Fig. 5, upper panel). By contradistinction, there was a difference between osmotic rates, and regulatory rates; thus, cells shrink/swell faster than they can regulate their volume by RVI or RVD. The osmotic phase occurs possibly by fast water movements across water channels, while regulatory responses need the slower membrane transporters to work.

The extent of cell volume recovery was near complete in both directions: $83.68 \pm 5.73 \%$ and $92.3 \pm 2.3 \%$ for $20 \%$ hypotonic $(n=6)$ and $20 \%$ hypertonic solutions ( $n=7)$, respectively (Fig. 5, lower panel).

The duration of the osmotic phase $\mathrm{T}_{\text {osm }}$ was not significantly different in cells exposed to $20 \%$ hypertonic ringer solution $(n=7)$ as compared to cells exposed to $20 \%$ hypotonic Ringer ( $n=6)$. $T_{\text {osm }}$ was $0.7 \pm 0.1 \mathrm{~min}$ in $20 \%$ hypertonic treated cells, and $1.3 \pm 0.3 \mathrm{~min}$ in $20 \%$ hypotonic treated cells (Fig. 4). The degree of cell shrinkage, i.e. the minimum in normalized scattered light $\Delta \mathrm{I} / \mathrm{I}_{0}$ (which reflected changes in cell volume) during hyperosmotic exposure was $0.08 \pm 0.01$ (arbitrary units), $(n=7)$, while the degree of cell swelling (the maximum in $\Delta \mathrm{I} / \mathrm{I}_{0}$ during hyposmotic exposure) was $0.07 \pm 0.02$ (arbitrary units), ( $\left.\mathrm{n}=6\right)$, without significant differences between them (Fig. 4). 


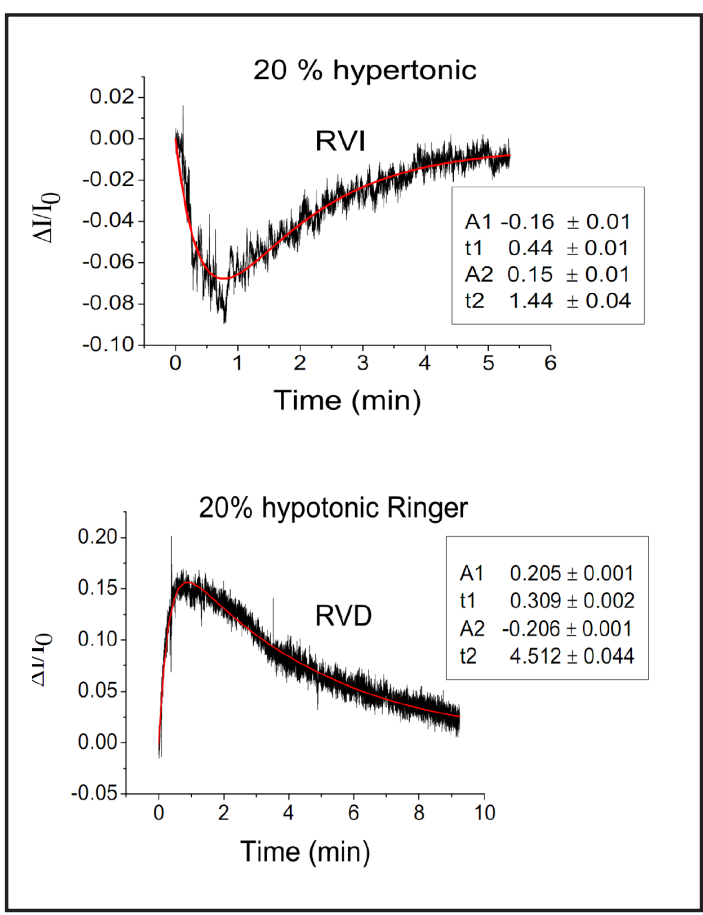

Fig. 3. Data fit to double exponential function for RVI and RVD in HL-1 cells. Upper panel. Representative experiment showing a RVI response in HL-1 cells after a $20 \%$ hypertonic solution challenge. The regulatory phase of the volume transient lasted approximately 6 min. (RVI), with a cell volume recovery of $98 \%$. Data was fit to a double exponential function, as described in Materials and Methods section. Curve fit is shown. The parameters of the double exponential fit are also shown. $\mathrm{R}^{2}$ : 0.97. Lower panel. Representative experiment showing RVD in HL-1 cells after a $20 \%$ hypotonic solution challenge. The regulatory phase of the volume transient lasted approximately $8 \mathrm{~min}$. Volume recovery was $97 \%$ for this experiment. Data was fit to a double exponential function, $\mathrm{R}^{2}$ : 0.97 . The parameters of the double exponential fit are also shown. Abbreviations used: A1, amplitude of the osmotic phase; $\mathrm{A} 2$, amplitude of the regulatory phase; $\mathrm{t} 1$, time constant for the osmotic response; $\mathrm{t} 2$, time constant for the regulatory response.

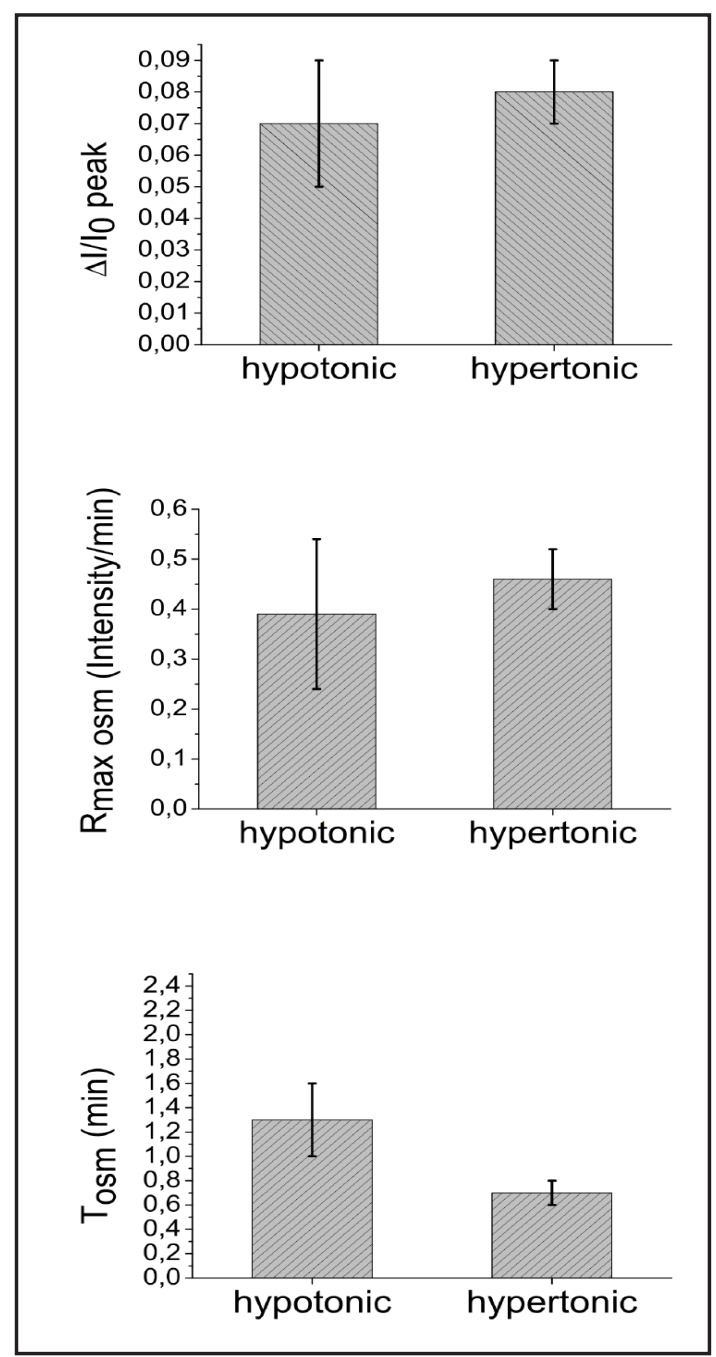

Fig. 4. Characteristics of cell swelling and cell shrinkage of HL-1 cells exposed to $20 \%$ hypotonic and 20 $\%$ hypertonic solutions. We show $\mathrm{R}_{\max \text { osm }}$ (maximum osmotic rate); $\mathrm{T}_{0 \mathrm{sm}}$ (osmotic time); $\Delta \mathrm{I} / \mathrm{I}_{0}$ peak (peak of normalized light scattered light after anisotonic challenge, in absolute values). We didn't find significant differences between hypotonic and hypertonic osmotic challenges at 0.05 significance level.

\section{Bumetanide inhibits the RVI response in HL-1 cardiac myocytes}

Since the $\mathrm{Na}^{+} / \mathrm{K}^{+} / 2 \mathrm{Cl}^{-}$cotransporter (NKCC) is involved in the RVI responses in many cell types, and is expressed in cardiac cells, we decided to examine the effect of its inhibitor bumetanide on the RVI response. Figure 6 shows a representative experiment. Volume recovery in control experiments (hypertonic alone) was $92.3 \pm 2.3 \%(n=7)$, while bumetanide $50 \mu \mathrm{M}$ significantly inhibited volume recovery, to $24.6 \pm 8.8 \%$ ( $\mathrm{n}=5$ ), (Fig. 7, upper panel). Bumetanide $50 \mu \mathrm{M}$ also significantly reduced the rate of RVI from $0.070 \pm$ 0.020 light intensity $/ \mathrm{min}(\mathrm{n}=7)$ under control (hypertonic) conditions, to $0.010 \pm 0.005$ light intensity/min. $(\mathrm{n}=5)$ in the presence of the inhibitor, (Fig. 7, lower panel). These results show that a bumetanide-sensitive mechanism is necessary for the RVI response of HL-1 cardiac myocytes. 


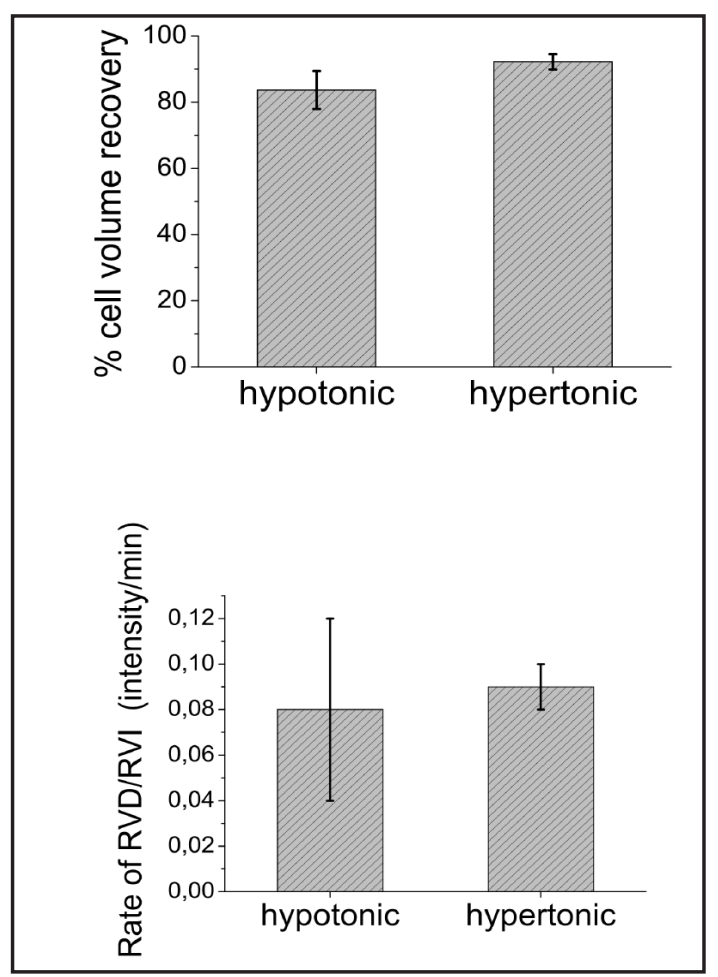

Fig. 5. Volume regulatory responses of HL-1 cells exposed to $20 \%$ hypotonic and $20 \%$ hypertonic solutions. Upper panel. \% cell volume recoveries by RVD and RVI are similar for both hypotonic and hypertonic challenge, respectively. Lower panel. Rates of RVD and RVI are similar too.

Fig. 7. Inhibition of the RVI response of HL-1 cells exposed to a $20 \%$ hypertonic solution in the presence of $50 \mu \mathrm{M}$ bumetanide (BUM) or $50 \mu \mathrm{M}$ DIDS. $\left({ }^{*}\right)$ denotes a significant result $(\mathrm{P}<0.05)$.

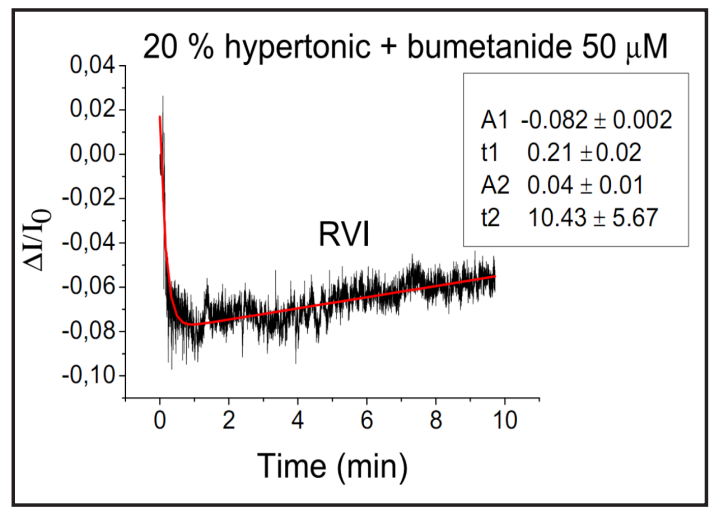

Fig. 6. Effect of $50 \mu \mathrm{M}$ bumetanide in the RVI response of HL-1 cells. RVI response was partially inhibited. Note the difference with the complete RVI in Fig 4. Cell volume recovery was $25 \%$ approximately at $10 \mathrm{~min}$. Curve fit to double exponential function is shown. Parameters of double exponential fit are also shown. $\mathrm{R}^{2}$ : 0.96. Abbreviations used: A1, amplitude of the osmotic phase; $\mathrm{A} 2$, amplitude of the regulatory phase; $\mathrm{t} 1$, time constant for the osmotic response; $\mathrm{t} 2$, time constant for the RVD response.
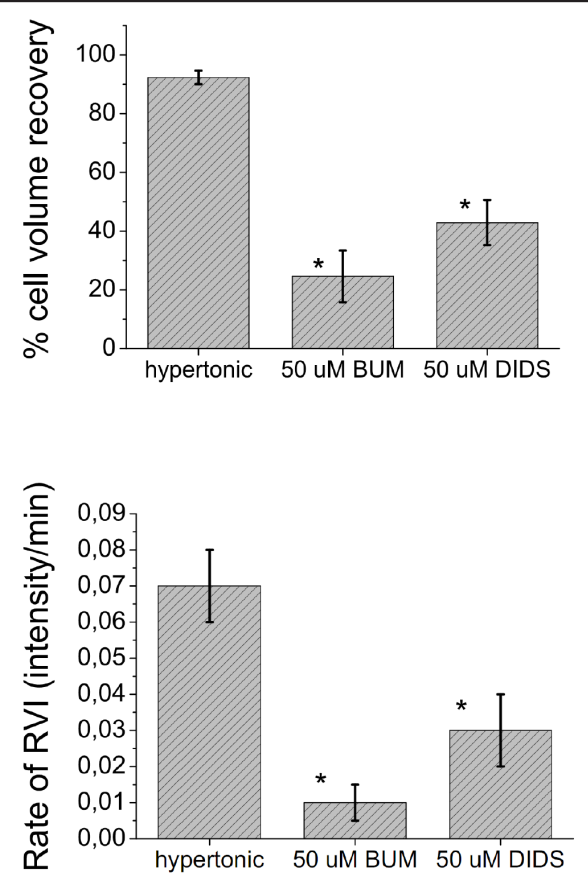

Bumetanide did not affect the duration of the osmotic phase and the degree of cell shrinkage

The duration of the cell shrinkage phase during hyperosmotic exposure $\mathrm{T}_{\text {osm }}$ was not significantly different in cells exposed to $20 \%$ hypertonic ringer solution with $50 \mu \mathrm{M}$ bumetanide $(\mathrm{n}=5)$ as compared to cells exposed to $20 \%$ hypertonic Ringer alone (control, $\mathrm{n}=7$ ). $\mathrm{T}_{\text {osm }}$ was $0.7 \pm 0.1 \mathrm{~min}$ in control cells and $0.6 \pm 0.2 \mathrm{~min}$ in bumetanide treated cells (Fig. 8, upper graph). 


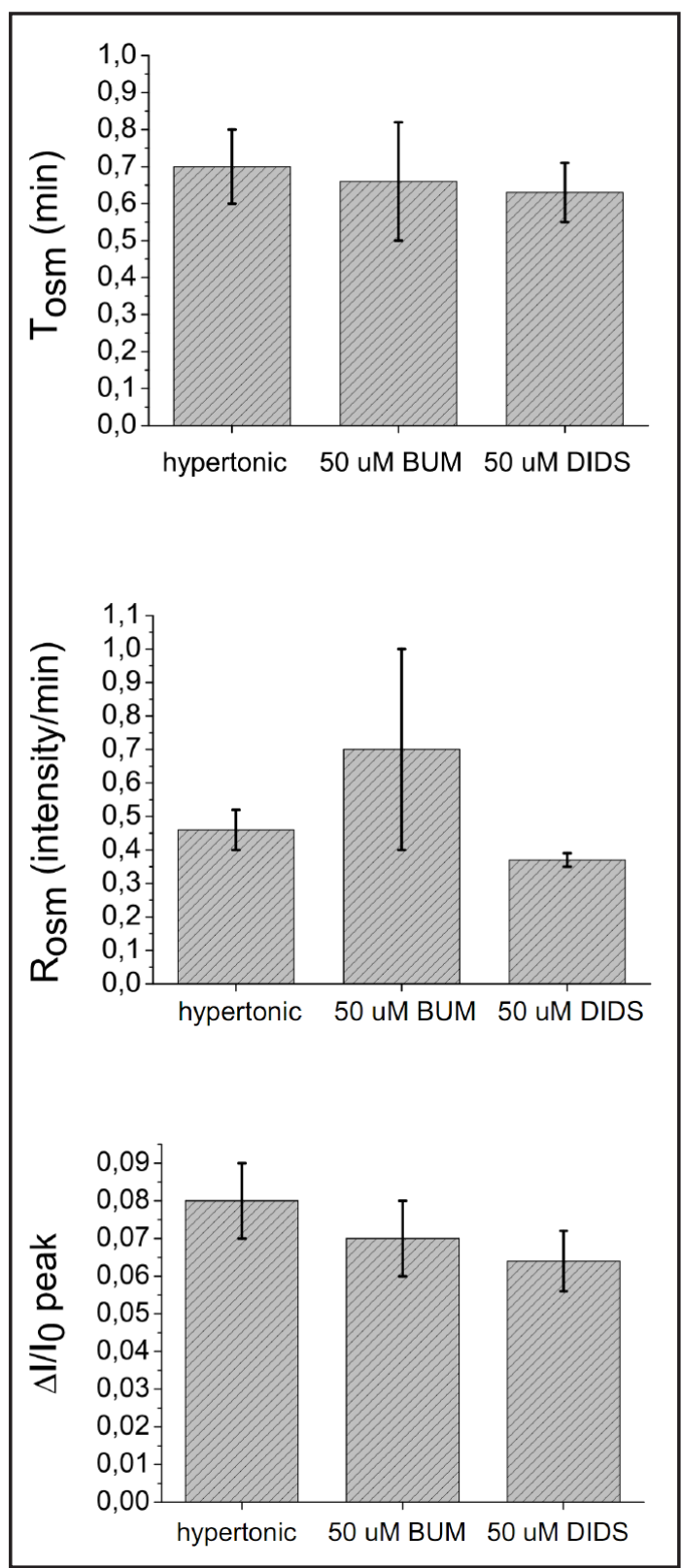

Fig. 8. The osmotic properties of HL-1 cells exposed to a $20 \%$ hypertonic solution was unaffected by 50 $\mu \mathrm{M}$ bumetanide (BUM) or $50 \mu \mathrm{M}$ DIDS.

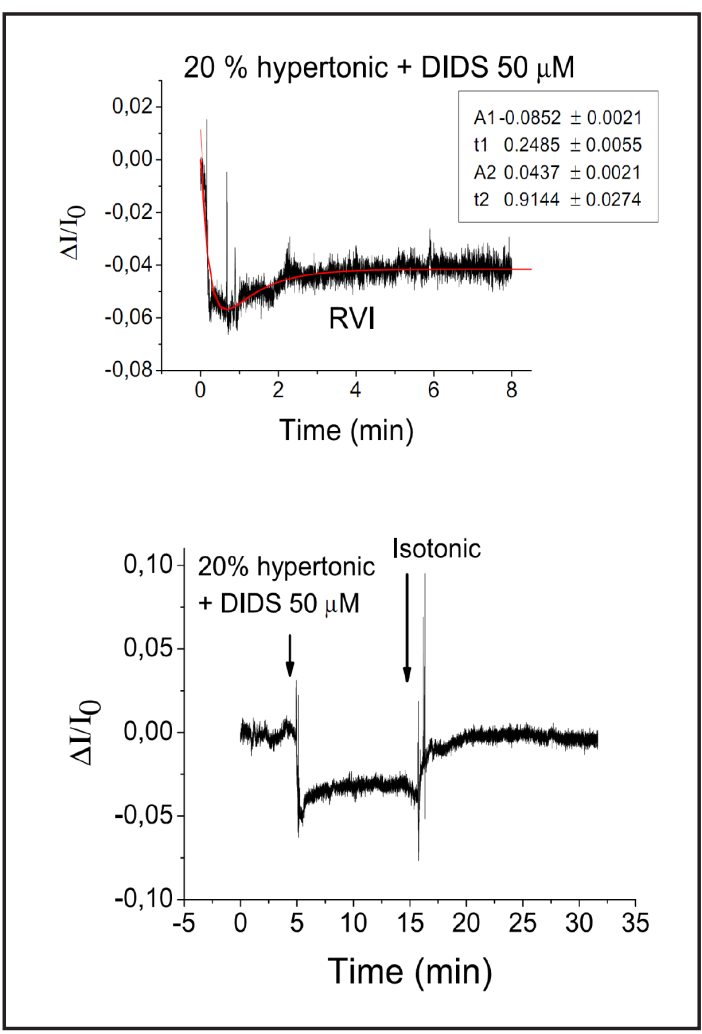

Fig. 9. Cell volume regulatory responses in DIDS treated HL-1 cells. Upper panel. Effect of $50 \mu \mathrm{M}$ DIDS in the RVI response of HL- 1 cells. Volume recovery at $\mathrm{t}=8 \mathrm{~min}$ was $34 \%$ for this experiment. Curve fit is shown. Parameters of double exponential fit are also shown. $\mathrm{R}^{2}$ : 0.87. Abbreviations used: A1, amplitude of the osmotic phase; $\mathrm{A} 2$, amplitude of the regulatory phase; $\mathrm{t} 1$, time constant for the osmotic response; t2, time constant for the RVD response. Lower panel. Representative experiment showing a $20 \%$ hypertonic challenge in presence of DIDS $50 \mu \mathrm{M}$ with additional inhibition of post regulatory RVD. Cells were incubated in isotonic Ringer in presence of 50 $\mu \mathrm{M}$ DIDS for $10 \mathrm{~min}$. and then were exposed to $20 \%$ hypertonic solution supplemented with DIDS $50 \mu \mathrm{M}$. RVI was inhibited. No post RVI-RVD was observed after return of cells to isotonic Ringer.

Rmax osm was $0.46 \pm 0.06$ light intensity/min in control experiments and $0.70 \pm 0.30$ light intensity/min in bumetanide treated cells (Fig. 8, centre graph) without significant differences between them. The degree of cell shrinkage, i.e. the minimum in normalized scattered light $\Delta \mathrm{I} / \mathrm{I}_{0}$ (which reflected changes in cell volume) during hyperosmotic exposure, was not significantly different in cells treated with $50 \mu \mathrm{M}$ bumetanide as compared to control. The minimum of normalized scattered light (maximum cell shrinkage) was $0.08 \pm$ 0.01 (arbitrary units) $(\mathrm{n}=7)$ in control cells (i.e. treated with $20 \%$ hypertonic Ringer alone), and $0.07 \pm 0.01$ in bumetanide treated cells (Fig. 8, bottom graph). 
DIDS partially inhibits the RVI response in $H L-1$ cardiac myocytes

To investigate the potential role of the $\mathrm{Cl}^{-} /$bicarbonate exchanger in the RVI response, we examined the effect of the $\mathrm{Cl}^{-} /$bicarbonate exchanger inhibitor DIDS. Figure 9 shows representative experiments. DIDS significantly reduced the extent of cell volume recovery by RVI, from $92.3 \pm 2.3 \%$ in controls $(n=7)$ to $42.93 \pm 7.7 \%$ in DIDS treated cells $(n=5)$, (Fig. 7, upper panel). $50 \mu \mathrm{M}$ DIDS also significantly reduced the temporal rate of RVI, from an average of $0.07 \pm 0.02$ light intensity/min under control conditions, to $0.03 \pm 0.01$ light intensity/min in the presence of $50 \mu \mathrm{M}$ DIDS, (n=5), (Fig. 7, lower panel). Clearly, a DIDSsensitive mechanism has a role in the RVI response of HL-1 cardiac myocytes.

DIDS does not have an effect on Tosm and the degree of cell shrinkage in HL-1 cells

$\mathrm{T}_{\text {osm }}$ and $\mathrm{R}_{\max \text { osm }}$ were not significantly different in cells exposed to $20 \%$ hypertonic ringer solution with $50 \mu \mathrm{M}$ DIDS as compared to control. $\mathrm{T}_{\text {osm }}$ was $0.7 \pm 0.1 \mathrm{~min}$ in control cells ( $n=7)$ and $0.63 \pm 0.08$ min in DIDS treated cells ( $n=5)$, (Fig. 8, upper graph). $R_{\text {max osm }}$ was $0.46 \pm 0.06$ light intensity $/ \mathrm{min}$ in control experiments, and $0.03 \pm 0.01$ light intensity $/ \mathrm{min}$ in DIDS treated cells (Fig. 8, centre graph). The degree of cell shrinkage was not significantly different in cells treated with DIDS $50 \mu \mathrm{M}$ as compared to control with hypertonic exposure alone. The maximum decrease in the scattered light $\Delta \mathrm{I} / \mathrm{I}_{0}$ (arbitrary units) was $0.08 \pm 0.01$ $(\mathrm{n}=7)$ in control cells, and $0.064 \pm 0.008(\mathrm{n}=6)$ in DIDS treated cells (Fig.8, bottom graph).

\section{Discussion}

Osmotic behaviour of $H L-1$ cells

In this study, we found that HL-1 cardiac myocytes respond to both hypotonic and hypertonic stress by cell swelling and cell shrinkage respectively. There does not seem to be a lot difference between these osmotic responses; the rates of cell swelling and cell shrinkage does not differ significantly in HL-1 cells. In agreement with this, $t_{\text {osm }}$ upon hypertonic challenge was in the same order of magnitude than the $t_{\text {osm }}$ upon hypotonic challenge. This could be due to the presence of water channels in the plasma membrane of HL-1 cells. It is presumed that the resulting permeability for these channels will be symmetrical for both inflow and outflow. It was previously reported that HL-1 cells express aquaporin 4 (AQP4) in plasmatic membrane [39], which could account for this water movement.

\section{RVD and RVI responses in $H L-1$ cells}

HL-1 cells show RVD response following hypotonic challenge, similar to responses seen in other cardiac atrial cells [16]. Moreover, HL-1 cardiac cells show abundant RVI responses. After repeated osmotic challenges in the same preparation (up to $4 \mathrm{X}$ ), cell regulatory responses continued were present and of similar magnitude.

To our knowledge, this is the first time that RVI is reported in isolated cardiac myocytes. There is an observation [40] of rabbit whole heart regaining initial volume after more than 50 min exposure to hypertonic solution, which may point to the presence of RVI in the whole rabbit heart. However, such phenomenon could not be attributed totally to the cardiac myocytes, which represent approximately the $56 \%$ of heart cell composition [41]. Nevertheless, in terms of cell volume myocytes represent about a $75 \%$ of the total volume of the heart [42] so the other cell types could have a lesser contribution to these results.

The current report of RVI in cardiac myocytes applies to a line of long-term cultured cells, which may imply some difference to the more usual fresh non-cultured myocytes or cultured cardiac myocytes. In addition, possibly, volume regulation is more sensitive to some of the experimental conditions such as the solution used, the temperature, or the way cells have been handled. As for RVD, a few authors have reported that it is lost at room temperature $[11,12]$. In our HL-1 cell model, both RVD and RVI did not disappear but were merely slowed in time (data not shown) when experiments were carried out at room temperature $\left(25^{\circ} \mathrm{C}\right)$. In a few cases, after maximum cell swelling/shrinkage, there is a lag period of about 3-6 
min. and then regulatory response starts; in other cases, the cells remain shrunken (data not shown). These observations may explain prior negative RVI observations. In addition, most of the prior research in heart cell volume regulation was done in ventricular myocytes rather than in atrial myocytes. Perhaps there are differences in the ability of different types of cardiac cells to develop a volume regulatory response.

\section{Dynamics of RVD and RVI processes}

The volume regulatory responses took approximately 6-11 min for hypertonic challenge, and 8-15 min for hypotonic challenge. The extent of cell volume recovery was similar between RVD and RVI. Furthermore, the rates of both processes were similar too. To be noted, this implies that the dynamics of both regulatory mechanisms are symmetrical even when there are different ionic channels and transporters involved.

\section{Post-regulatory responses in cardiac cells}

Following a steady-state RVD, the change of the extracellular environment to an isotonic one promotes cell shrinkage as an osmotic response, and a post RVD-RVI. This response could imply that the prior RVD process had caused a significant decrease in the intracellular ionic concentrations. Similarly, in pathological conditions such as ischemia-reperfusion, cell swelling is observed $[43,44]$. It can be argued that such cell swelling might induce an RVD. After these events, reperfusion would act a bathing with isotonic solution, that is, it would induce cell shrinkage followed by a post RVD-RVI. If the reperfusion changes the extracellular ionic concentrations gradually, these processes could occur transiently during ischemia-reperfusion. Typically cell swelling is observed after reperfusion [43, 44], which may be the final consequence of the ionic imbalances that the reperfusion induces.

Regulatory responses in presence of bumetanide $50 \mu M$ and DIDS $\mu M$ : Bumetanide and DIDS inhibit RVI response

Cardiac cells express a large amount of transporters and ion channels, many of which have a function in cell volume down-regulation (RVD) in other cells [9]. Of course it is not known which molecules participate in the RVI of cardiac myocytes. However, it is expected that many of the same transporters and channels that participate in RVI in other cell types would likewise account for the present results.

Sodium-independent chloride-bicarbonate exchangers are present in the plasmatic membranes of many cell types, and function in the regulation of $\mathrm{pHi},\left[\mathrm{Cl}^{-}\right] \mathrm{i}$, and cell volume. Cardiac myocytes express different isoforms of electrogenic $\mathrm{Cl}^{-} / \mathrm{HCO}^{-}$exchangers [4547], which mediate $\mathrm{pH}$ regulation, and possibly contribute to maintenance of [Cl-]I [47, 48]. These exchangers have been extensively studied in heart muscle in the context of $\mathrm{pH}$ regulation. However, the role of $\mathrm{Cl}^{-} / \mathrm{HCO3}^{-}$exchangers in cardiac cell volume regulation is unknown.

In adition, cardiac myocytes also express the $\mathrm{Na}^{+} / \mathrm{K}^{+} / 2 \mathrm{Cl}^{-}$cotransporter $[5,49] . \mathrm{Na}^{+} /$ $\mathrm{K}^{+} / 2 \mathrm{Cl}^{-}$cotransport plays an important role in regulating cell volume in a number of tissues [50-52]. Measurements of cardiac cell volume suggest that $\mathrm{Na}^{+} / \mathrm{K}^{+} / 2 \mathrm{Cl}$ cotransport contributes to both the maintenance of cell volume under isotonic conditions and in response to osmotic stress $[10,53]$.

In the present study we found evidence for the involvement of the $\mathrm{Na}^{+} / \mathrm{K}^{+} / 2 \mathrm{Cl}^{-}$ cotransporter and $\mathrm{Cl} /$ Bicarbonate exchanger in the RVI response of atrial HL-1 cells. According to our results, bumetanide (specific inhibitor of the $\mathrm{Na}^{+} / \mathrm{K}^{+} / 2 \mathrm{Cl}^{-}$cotransporter) and DIDS (inhibitor of $\mathrm{Cl}^{-}$/Bicarbonate exchanger) inhibit the RVI response of HL-1 cardiac cells. Both inhibitors reduce the rate of RVI and as a result the cells present an incomplete regulatory response. The most likely explanation is that in the presence of the inhibitor alternative mechanisms of RVI are still functional. As might have been expected, no effect on RVD was seen in HL-1 cells exposed to $20 \%$ hypotonic solution in presence of $50 \mu \mathrm{M}$ bumetanide (data not shown); such a result has been previously reported for corneal endothelium cells [37]. Moreover, there is no inhibition of post RVI - RVD in HL-1 cells when 
cells previously exposed to hypertonic solution are returned to isotonic solution (data not shown). On the other hand, post RVI-RVD is inhibited by DIDS (Figure 9, lower panel). This result could be due to inhibition of electroneutral $\mathrm{KCl}$ cotransport (KCCs) or $\mathrm{Cl}^{-}$channels involved in RVD [54; 55]. KCl cotransporters have been described in heart cells [56] and a role was suggested for $\mathrm{KCl}$ cotransport in cardiac myocyte RVD [57].

\section{Conclusion}

In summary, results of the present study showed that in HL-1 myocytes anisotonic challenge is followed by efficient volume regulatory responses (RVD and RVI), and that RVI can be inhibited by both bumetanide and DIDS, which point to both NKCC and $\mathrm{Cl}^{-} /$ bicarbonate transporters being involved in the RVI response in these cells. Since the HL-1 cells are phenotypically and functionally similar to adult murine atrial cardiomyocytes [32], these current results could be extended to other atrial cardiomyocytes. Current investigations involve further characterization of these volume regulatory responses, with the aim of determining whether these properties of cardiac cells may be related to pathological conditions.

\section{Abbreviations}

RVD, (regulatory volume decrease); RVI, (regulatory volume increase); $A_{1}$, (the (signed) amplitude of the osmometric response); $A_{2}$, (the (signed) amplitude of the regulatory volume response); $t_{1}$, (the time constant for the osmotic response); $t_{2}$, (the time constant for the RVD or RVI responses); $\mathrm{Y}_{0}$, (is the volume at zero time); $\mathrm{R}_{\max ^{\prime}}$ average maximum rate for osmotic phase); $\mathrm{R}_{\text {max }}$ (average maximum rate for regulatory response); $\mathrm{T}_{\text {osm }}$ (osmotic time); DIDS, (4,4'-Diisothiocyano-2,2'-stilbenedisulfonic acid).

\section{Acknowledgments}

HL-1 cells were gently provided by Dr. William Claycomb, Department of Biochemistry and Molecular Biology, University of Louisiana, USA. We thank Dra. Patricia Bonazzola for her guidance and help in correcting the manuscript. VIC held a CONICET post-graduate fellowship. This work was supported by CONICET grant PIP 0810 (to Dr. Jorge Fischbarg and Dr. Lydia Costa), and by a grant from the Agencia Nacional de Promoción Científica y Tecnológica (ANPCyT), to Dra. Karina A. Gomez.

\section{References}

1 Lang F, Busch GL, Ritter M, Völkl H, Waldegger S, Gulbins E, Häussinger D: Functional significance of cell volume regulatory mechanisms. Physiol Rev 1998;78:247-306.

-2 Wehner F, Olsen H, Tinel H, Kinne-Saffran E, Kinne RK: Cell volume regulation: osmolytes, osmolyte transport, and signal transduction. Rev. Physiol Biochem. Pharmacol 2003;148:1-80.

- Hoffmann EK, Lambert IH, Pedersen SF: Physiology of cell volume regulation in vertebrates. Physiol Rev 2009;89:193-277.

4 Lang F: Mechanisms and significance of cell volume regulation. J Am Coll Nutr 2007; 26: 613-623.

5 Pedersen SF, O'Donnell ME, Anderson SE, Cala PM: Physiology and pathophysiology of $\mathrm{Na}^{+} / \mathrm{H}^{+}$exchange and $\mathrm{Na}^{+}-\mathrm{K}^{+}-2 \mathrm{Cl}$ cotransport in the heart, brain, and blood. Am J Physiol Regul Integr Comp Physiol 2006;291:R1-R25.

6 Qusous A, Geewan CS, Greenwell P, Kerrigan MJ: siRNA-mediated inhibition of $\mathrm{Na}^{+}-\mathrm{K}^{+}-2 \mathrm{Cl}^{-}$cotransporter (NKCC1) and regulatory volume increase in the chondrocyte cell line C-20/A4. J Membr Biol 2011;243:2534. 


\section{Cellular Physiology $\quad$ Cell Physiol Biochem 2014;33:1745-1757 and Biochemistry

7 O'Neill WC: Physiological significance of volume-regulatory transporters. Am J Physiol 1999;276:995-1011.

8 Strange K: Cellular volume homeostasis. Adv Physiol Educ 2004;28:155-159.

9 Wright AR, Rees SA: Cardiac Cell Volume: Crystal Clear or Murky Waters? A Comparison with Other Cell Types. Pharmacol Ther 1998;80:89-121.

10 Drewnowska K, Baumgarten CM: Regulation of cellular volume in rabbit ventricular myocytes: bumetanide, chlorthiazide and ouabain. Am J Physiol 1991;260:122-C131.

11 Suleymanian MA, Baumgarten CM: Osmotic gradient-induced water permeation across the sarcolemma of rabbit ventricular myocytes. J Gen Physiol 1996;107:503-514.

12 Hall SK, Zhang J, Lieberman M: A nearly transient current is associated with hyposmotic swelling and volume Regulation in embryonic chick cardiac myocytes. Exp Physiol 1997;82:43-54.

13 Wang Z, Mitsuiye T, Rees SA, Noma N: Regulatory volume decrease of cardiac myocytes induced by betaadrenergic activation of the $\mathrm{Cl}^{-}$channel in guinea pig. J Gen Physiol 1997;110:73-82.

14 Yamamoto, S., Ishihara K, Ehara T, Shioya T: Cell-volume regulation by swealling-activated chloride current in guinea pig ventricular myocytes. Jpn J Physiol 2004;54:31-38.

15 Shi L, Xu M, Liu J, Zhang Z, Bao Z, Wang Y, Wang C, Wang J: KATP Channels Are Involved in Regulatory Volume Decrease in Rat Cardiac Myocytes. Physiol Res 2009;58:645-652.

16 Xiong D, Wang GX, Burkin DJ, Yamboliev YA, Singer CA, Rawat S, Scowen P, Evans R, Ye L, Hatton WJ, Tian H, Keller PS, McCloskey DT, Duan D, Hume JR: Cardiac-specific overexpression of the human short CLC-3 chloride channel isoform in mice. Clin Exp Pharmacol Physiol 2009;36:386-393.

17 Rasmusson RL, Davies D, Lieberman M: Aminoacid loss during volume regulatory decrease in cultured chick heart cells. Am J Physiol 1993;264:136-145.

18 Zhang J, Rasmusson RL, Hall SK, Lieberman M: A chloride current associated with swelling of cultured chick heart cells. J Physiol 1993;472:801-820.

19 Diaz RJ, Batthish M, Hinek A, Wilson GJ: Regulatory volume decrease requires $\mathrm{Cl}^{-}$channel activation in rabbit ventricular myocytes. J Mol Cell Cardiol 2001;33: Doi:10.1016/S0022-2828(01)90109-9.

-20 Díaz-Elizondo J, Chiong M, Rojas-Rivera D, Olea-Azar C, Kwon HM, Lavandero S: Reactive oxygen species inhibit hyposmotic stress-dependent volume regulation in cultured rat cardiomyocytes. Biochem Biophys Res Commun 2006;350:1076-1081.

21 Bell JR, Lloyd D, Curl CL, Delbridge LM, Shattock, MJ: Cell volume control in phospholemman (PLM) knockout mice: do cardiac myocytes demonstrate a regulatory volume decrease and is this influenced by deletion of PLM? Exp Physiol 2009;94:330-343.

-22 Yamamoto S, Kita S, Iyoda T, Yamada T, Iwamoto T: New molecular mechanisms for cardiovascular disease: cardiac hypertrophy and cell-volume regulation. J Pharmacol Sci 2011;116:343-349.

23 Yamamoto S, Toshiki Y, Iyoda T, Satomi K, Takahiro I: Role of $\mathrm{Cl}^{-}$channels and transporters in cardiac cell volume homeostasis. Med Bull. Fukuoka Univ 2009;36:243-255.

24 Galvez A, Morales MP, Eltit JM, Ocaranza P, Carrasco L, Campos X, Sapag-Hagar M, Díaz-Araya G, Lavandero $\mathrm{S}$ : A rapid and strong apoptotic process is triggered by hyperosmotic stress in cultured rat cardiac myocytes. Cell Tissue Res 2003; 304:279-285.

25 Mizutani S, Prasad SM, Sellitto AD, Schuessler RB, Damiano RJ, Lawton JS: Myocyte Volume and Function in Response to Osmotic Stress: Observations in the Presence of an Adenosine Triphosphate-Sensitive Potassium Channel Opener. Circulation 2005;112:219-223.

-26 Tranum-Jensen J, Janse MJ, Fiolet WT, Krieger WJ, D’Alnoncourt CN, Durrer D: Tissue osmolality, cell swelling, and reperfusion in acute regional myocardial ischemia in the isolated porcine heart. Circ Res 1981;49: 64-381.

27 Dibona DR, Powell WJ: Quantitative correlation between cell swelling and necrosis in myocardial ischemia in dogs. Circ Res 1980;47:653-665.

28 Carmeliet E: Cardiac ionic currents and acute ischemia: from channels to arrhythmias. Physiol Rev 1999;79:917-1017.

29 Falck G, Schjott J, Bruvold M, Krane J, Skarra S, Jynge P: Hyperosmotic perfusion of the beating rat heart and the role of the $\mathrm{Na}^{+} / \mathrm{K}^{+} / 2 \mathrm{Cl}^{-}$co-transporter and the $\mathrm{Na}^{+} / \mathrm{H}^{+}$exchanger. Basic Res Cardiol 2000;95:19-27.

-30 Fischbarg J, Li J, Kuang K, Echavarria M, Iserovich P: Determination of volume and water permeability of plated cells from measurements of light scattering. Am J Physiol 1993;265:1412-23.

-31 Echevarria M, Kuang K, Iserovich P, Li J, Preston GM, Agre P, Fischbarg J: Cultured bovine corneal endothelial cells express CHIP28 water channels. Am J Physiol Cell Physiol 1993;265:1349-1355. 


\section{Cellular Physiology $\quad$ Cell Physiol Biochem 2014;33:1745-1757 and Biochemistry \\ Cacace et al.: Cell Volume Regulation in HL-1 Cardiac Myocytes}

-32 Claycomb WC, Lanson NA, Stallworth BS, Delcarpio DB, Izzo,JR NJ: HL-1 cells: A cardiac muscle cell line that contracts and retains phenotypic characteristics of the adult cardiomyocyte. Proc Natl Acad Sci USA 1998;95:2979-2984.

-33 McManus M, Fischbarg J, Sun A, Hebert S, Strange K: Laser light-scattering system for studying cell volume regulation and membrane transport processes. Am J Physiol 1993;265:C562-C570.

34 Iserovich P, Reinach PS, Yang H, Fischbarh J: A novel approach to resolve cellular volume responses to an anisotonic challenge. Adv Exp Med Biol 1998;438:687-692.

-35 Hara E, Reinach PS, Wen Q Iserovich P, Fischbarg J. Fluoxetine inhibits $\mathrm{K}^{+}$transport pathways $\left(\mathrm{K}^{+}\right.$efflux, $\mathrm{Na}^{+}-\mathrm{K}^{+}-2 \mathrm{Cl}^{-}$cotransport, and $\mathrm{Na}^{+}$pump) underlying volume regulation in corneal endothelial cells. J Membr Biol 1999;171:75-85.

-36 Srinivas SP, Bonanno JA, Larivière E, Jans D, Van Driessche W: Measurement of rapid changes in cell volume by forward light scattering. Pflugers Arch Eur J Physiol 2003;447:97-108.

-37 Kuang K, Yiming M, Zhu M, Iserovich P, Diecke FP, Fischbarg J: Lack of threshold for anisotonic cell volume regulation. J Membr Biol 2006;211:27-33.

38 Wu X, Yang H, Iserovich P, Fischbarg J, Reinach PS: Regulatory volume decrease by SV40-transformed rabbit corneal epithelial cells requires ryanodine-sensitive $\mathrm{Ca}^{2+}$-induced $\mathrm{Ca}^{2+}$ release. J Membr Biol 1997;158:127136.

39 Mace LC, Yermalitskaya LV, Yi Y, Yang Z, Murray KT: Transcriptional remodeling of rapidly stimulated HL-1 atrial myocytes exhibits Concordance with Human Atrial Fibrillation. J Mol Cell Cardiol 2009;47:485-492.

40 Ho HS, Liu H, Cala PM, Anderson SE: Hypertonic perfusion inhibits intracellular $\mathrm{Na}^{+}$and $\mathrm{Ca}^{2+}$ accumulation in hypoxic myocardium. Am J Physiol Cell Physiol 2000;278:C953-C964.

41 Banerjee I, Fuseler JW, Price RL, Borg TK, Baudino TA: Determination of cell types and numbers during cardiac development in the neonatal and adult rat and mouse. Am J Physiol Heart Circ Physiol 2007;293:1883-1891.

-42 Brilla CG, Janicki JS, Weber KT: Impaired diastolic function and coronary reserve in genetic hypertension. Role of interstitial fibrosis and medial thickening of intramyocardial coronary arteries. Circ Res 1991;69:107-115.

43 Powers ER, DiBona DR, Powell Jr WJ: Myocardial cell volume and coronary resistance during diminished coronary perfusion. Am J Physiol Heart Circ Physiol 1984;247:H467-H477.

44 Jennings RB, Schaper J, Hill ML, Steenbergen CR Jr, Reimer KA: Effect of reperfusion late in the phase of reversible ischemic injury. Changes in cell volume, electrolytes, metabolites, and ultrastructure. Circ Res 1985;56:262-278.

45 Heinemeyer D, Bay W: Intracellular pH in quiescent and stimulated ventricular myocardium: effect of extracellular chloride concentration. Pflugers Arch 1987;409:142-144.

46 Polimeni PI, Page E: Chloride distribution and exchange in rat ventricle. Am J Physiol 1980;238:C169-C176.

47 Kim HJ, Myers R, Sihn SC, Rafizadeh S, Zhang XD: Slc26a6 functions as an electrogenic $\mathrm{Cl}^{-} / \mathrm{HCO}_{3}{ }^{-}$exchanger in cardiac myocytes. Cardiovasc Res 2013;100:383-391.

48 Vaughan-Jones RD: Chloride activity and its control in skeletal and cardiac muscle. Phil Trans R Soc Lond 1982;299:537-548.

49 Clemo HF, Feher JJ, Baumgarten CM: Modulation of Rabbit Ventricular Cell Volume and $\mathrm{Na}^{+} / \mathrm{K}^{+} / 2 \mathrm{C} 1$ Cotransport by cGMP and Atrial Natriuretic Factor. J Gen Physiol 1992;100:89-114.

50 Eveioff JL, Warnock DG: Activation of ion transport systems during cell volume regulation. Am J Physiol 1987;252:F1-F10.

51 Hoffman EK, Simonsen LO: Membrane mechanisms in volume and pH regulation in vertebrate cells. Physiol Rev 1989;69:315-382.

52 Russell JM: Sodium-Potassium-Chloride Cotransport. Physiol Rev 2000;80:211-266.

53 Clemo HF, Baumgarten CM: Atrial natriuretic factor decreases cell volume of rabbit atrial and ventricular myocytes. Am J Physiol 1991;260:C681-C690.

54 Strange K: Volume regulatory $\mathrm{Cl}^{-}$loss after $\mathrm{Na}^{+}$pump inhibition in CCT principal cells. Am J Physiol 1991;260:F225-34.

55 Delpire E, Lauf PK: Kinetics of DIDS inhibition of swelling-activated K-Cl cotransport in low K sheep erythrocytes. J Memb Biol 1992;126:89-96.

-56 Adragna NC, Lauf PK: K-Cl cotransport function and its potential contribution to cardiovascular disease. Pathophysiology 2007;14:135-146.

57 Taouil K, Hannaert P: Evidence for the involvement of $\mathrm{K}^{+}$channels and $\mathrm{KCl}$ cotransport in the regulatory volume decrease of newborn rat cardiomyocytes. Pflügers Arch - Eur J Physiol 1999;439:56-66. 